\title{
The Relevance of Legal Protection to Human Rights Related to Euthanasia Law in Indonesia
}

\author{
Yusriyanto Kadir ${ }^{1}$ \\ Leni Dwi Nurmala ${ }^{2}$ \\ Nurwita Ismail $^{3}$
}

\footnotetext{
${ }^{1}$ Faculty of Law Gorontalo University. Gorontalo, Indonesia, E-Mail: Yusrikadir@gmail.com

${ }^{2}$ Faculty of Law Gorontalo University. Gorontalo, Indonesia, E-Mail: lenitsaina@gmail.com

${ }^{3}$ Faculty of Law Gorontalo University. Gorontalo, E-Mail: nhurwita.ismail@gmail.com
}

\section{Article Info \\ Keywords: \\ Human rights; Right to \\ life; Euthanasia \\ How to cite (APA Citation Style): \\ Kadir, Y., Nurmala, L.D., Ismail, N. (2021). " The \\ Relevance of Legal \\ Protection to Human \\ Rights Related to \\ Euthanasia Law in \\ Indonesia". Jambura Law \\ Review. JALREV 3 (2): \\ 319-335}

\begin{abstract}
Every human being has rights that have been given since humans are in and the right to life is an absolute right that must be lived by every human being. Law Number 39 of 1999 concerning Human Rights does not provide space for euthanasia because euthanasia is contrary to the provisions of the Human Rights Law, especially the right to life of a person. The right to life in Law Number 39 of 1999 concerning Human Rights explains that every human being or every person without exception has the right to life, the right not to be tortured, the right to personal freedom thought and conscience, the right to religion, the right not to be enslaved, the right to recognized as a person and equality before the law, and the right not to study based on applicable law is a human right that cannot be reduced under any circumstances and by anyone.
\end{abstract}

(C) 2021 - Kadir, Y., Nurmala, L.D., Ismail, $\mathrm{N}$

Under the license CC BY-SA 4.0

\section{Introduction}

The most fundamental human right is the right to life. The right to life is a moral principle based on the belief that every human being has it and this right to life is owned by every person/citizen from birth to the end of his life. Article 28A of the 1945 Constitution of the Republic of Indonesia states that everyone has the right to live and has the right to defend his life and life. Human Rights, namely basic rights that are owned from birth. Human rights are rights inherent in the individual person, and this 
right is the most basic for every individual to stand and live independently in society. ${ }^{1}$ In various international instruments, human rights have received significant attention. We can see that the Basics of Human Rights are contained in the instrument Universal Nations of Human Rights, International Covenant on Civil and Political Rights, International Covenant on Economic. Social and Cultural Rights. ${ }^{2}$

The issue of human rights from day to day, has occupied a very important position and is increasing in today's world. Today, the issue of human rights is not just a slogan that is raised and discussed everywhere, but more than that. The phenomenon of human rights that exists today, has become the center of attention of international organizations and humanitarian institutions, which then gives birth to intense concern and competition to foster support for thought and culture. ${ }^{3}$

Advances in science and technological progress have been going so fast and amazingly, especially in the development of health technology in this case medical science technology so that it can provide health services to the community to the maximum and can be given a modern treatment. It is indeed a privilege for our nation and country, the Republic of Indonesia, the development of science, especially technology in the field of medicine in our country which is developing and has led to the advancement of modern technology. The development of modern medical science and supported by the existence of places of education and support by experts as well as sophisticated and very complete and modern equipment that is ready to provide health services for the community. In line with these advanced technologies, the demand for health services has increased, but many have also caused problems in medical practice. Human nature always wants a healthy life, both physically and mentally. But human desires are not always fulfilled. In life, humans sometimes get sick or suffer from a disease. The condition of humans who experience a disease can be caused by various

\footnotetext{
${ }^{1}$ Harifin A Tumpa. (2009). "Peluang dan tantangan Eksistensi Pengadilan HAM di Indonesia". Makassar: PUKAP Indonesia.

2 Dewi Lestari. (2007). "Hak Asasi Manusia Di In. donesia Ditinjau Dari Berbagai Aspek Kehidupan”. Jurnal Hukum \& Pembangunan 37 (4): 499.

3 Sukarwarsini Djelantik. (2006). "Diplomasi Hak Asasi Manusia Tantangan Bagi Indonesia”. Jurnal Hukum Pro Justitia 24 (4): 410-425.
} 
things that exist in the human being. Either caused by things that exist in humans ranging from weakened immune systems (body immunity) or which are often caused by exposure to germs, viruses or parasites. Other causes can be caused by not implementing a healthy lifestyle, an inappropriate, unhygienic living environment or due to certain health problems. So that the life of a human being is sick or suffering from a disease.

Euthanasia is one of the social problems in the health sector that has occurred in society, especially in the health sector. Euthanasia in Indonesia some time ago became a hot topic of discussion among human rights activists, legal observers and the medical world. Euthanasia is an act of ending someone's life that is done intentionally, to relieve pain, relieve suffering from someone who is experiencing a certain disease. Euthanasia is the termination of a human or animal life through a method that is considered painless or causes minimal pain, usually done by giving an injection that can have an effect in the form of death. This is done because people who experience a certain disease are considered to have no more hope of being healthy or recovering. A patient who suffers from a very severe disease that cannot be cured again can apply to end his life by stopping a treatment or by being given an injection. ${ }^{4}$

Euthanasia was once performed at the request of Belgian Paralympic athlete, Marieke Vervoort. A doctor's injection ended the 40-year-old woman's life in October 20195 . Belgium is one of the countries that recognize and legalize euthanasia. Legal recognition of euthanasia is even earlier in the Netherlands. However, most countries do not recognize and justify the act of euthanasia. Indonesia is one of those who do not recognize the right to end one's life, this is contrary to the most fundamental human rights, namely the right to life. The pros and cons of euthanasia to date continue to experience quite a complicated and endless debate.

\footnotetext{
${ }^{4}$ Rospita A. Siregar. (2015). "Eutanasia Dan Hak Asasi Manusia". Jurnal Hukum To-Ra Hukum Untuk Mengatur dan Melindungi Masyarakat FH UKI 1 (3): 193.

${ }^{5}$ Hukum Online. "Euthanasia di Indonesia, Masalah Hukum dari Kisah-kisah yang Tercatat". Retrieved from https://www.hukumonline.com/berita/baca/lt5dd4f5e2a4f7f/euthanasia-di-indonesia-masalah-hukum-dari-kisah-kisah-yang-tercatat . Accessed on Apri, 2020.
} 


\section{Problem Statement}

As for the limitations in the discussion of this writing, the author wants to examine in depth the relevance of legal protection to human rights related to euthanasia law in Indonesia. The extent to which Indonesian law provides protection regarding the existence of Euthanasia and the protection of Human Rights in the form of guarantees and protection of the rights of human life.

\section{Method/ Approach}

The writing method used is literature study, which is a method of searching and finding, and obtaining data by collecting and studying theories and opinions of scholars and experts. This researcher uses a normative juridical approach to problems, namely by processing and analyzing legal regulations ${ }^{6}$. Normative legal research always focuses on secondary data sources. Normative legal research always focuses on secondary data sources. Secondary data in this study were obtained from legal materials as follows: Primary legal materials, consisting of legislation namely the 1945 Constitution of the Republic of Indonesia, the Criminal Code, Law no. 39 of 1999 on Human Rights and other related regulations and Secondary legal materials, consisting of books and the results of previous research.

\section{Discussion}

\subsection{Legal Protection of Human Rights related to Euthanasia in Indonesia} Talking about legal protection, this is one of the most important elements of a rule of law. It is considered important because in the formation of a state there will also be a law that regulates each of its citizens. It is common to know that a country will have a reciprocal relationship between its citizens. In this case, it will give birth to a right and obligation to each other. Legal protection will be the right of every citizen. But on the

\footnotetext{
${ }^{6}$ Soerjono Soekanto and Sri mamudji. (2001). "Penelitian Hukum Normatif: Suatu Tujuan Singkat, Ed. V". Jakarta: Raja Grafindo Persada. p. 13-14 .
} 
other hand, it can also be felt that legal protection is an obligation for the state itself, therefore the state is obliged to provide legal protection to its citizens. ${ }^{7}$

Legal protection is a protection given to legal subjects in the form of tools, both preventive and repressive, both verbal and written. In other words, it can be said that legal protection is a separate picture of the function of the law itself, which has the concept that the law provides justice, order, certainty, benefit, and peace.

In carrying out and providing legal protection, a place or container in its implementation is needed which is often referred to as a means of legal protection. Means of legal protection are divided into two types which can be understood, as follows:

Preventive Legal Protection Means. In this preventive legal protection, legal subjects are given the opportunity to submit objections or opinions before a government decision gets a definitive form. The goal is to prevent disputes from occurring. Preventive legal protection is very meaningful for government actions based on freedom of action because with the existence of preventive legal protection the government is encouraged to be careful in making decisions based on discretion. In Indonesia, there is no specific regulation regarding preventive legal protection. Means of Repressive Legal Protection. Repressive legal protection aims to resolve disputes. The handling of legal protection by the General Courts and Administrative Courts in Indonesia belongs to this category of legal protection. The principle of legal protection against government actions rests and originates from the concept of recognition and protection of human rights because according to history from the west, the birth of concepts regarding the recognition and protection of human rights is directed at the limitations and laying down of community obligations. and government.

The second principle that underlies legal protection against acts of government is the rule of law. Associated with the recognition and protection of human rights, the

\footnotetext{
${ }^{7}$ Nuswantoro Dwiwarno Ita Iya Pulina Perangin-angin, Rahayu. (2019). “Kewajiban Dan Tanggungjawab Negara," Diponegoro Law Journal 8 (1): 457-483.
} 
recognition, and protection of human rights has the main place and can be linked to the objectives of the rule of law. ${ }^{8}$

\subsection{Euthanasia in Indonesian Law}

Euthanasia is derived from the Greek EU which means "good", and Thanatos, which means "death". ${ }^{9}$ According to medical terms, euthanasia means the act of reducing the pain or suffering experienced by someone who is about to die. It also means hastening the death of someone who is in great pain and suffering before his death. 10

Euthanasia in the Oxford English Dictionary is defined as "a gentle and comfortable death, carried out especially in the case of a painful and incurable disease". A very popular term for this type of killing is mercy killing. Meanwhile, according to the Dorland Medical Dictionary, euthanasia has two meanings: First, an easy or painless death. Second, the merciful killing, the careful and deliberate ending of the life of a person suffering from an incurable and very painful disease. ${ }^{11}$

Euthanasia can be interpreted as a good form of death which according to some is considered a good thing. In the process of euthanasia death with a person (patient) who should have received and or is being treated by a doctor, actually, there has been a murder based on "mercy" (mercy killing). This type of homicide usually arises from the situation of the patient whose illness does not go away. For doctors, he can play a major role in realizing euthanasia as a way of realizing mercy killing. The role and actions of the doctor, such as:

1) It leaves a patient who should receive treatment (passive);

2) He gave too low or too high a dose (active);

\footnotetext{
${ }^{8}$ Jumiati, “Materi Negara Hukum Dan Hak Asasi Manusia Dalam Pembelajaran Di Sekolah Menengah," Demokrasi V, no. 2 (2006).

${ }^{9}$ Setiawan Budi Utomo, Fiqih Aktual Jawaban Tuntas Masalah Kontemporer, Jakarta, 2003, hal. 177.

10 M.Ali Hasan, Masail Fiqhiyah Al-Haditsah Pada Masalah-Masalah Kontemporer Hukum Islam, Jakarta, RajaGrafindo Persada, 1995 hal. 145

11 Tongat, Hukum Pidana Materiil, Malang: UMM Press, 2003, Hal 44.
} 
3) He gives medicine that is not in accordance with its designation.

The term euthanasia or mercy killing (killing based on a sense of "mercy") Killing at the request of the victim is a type of murder.

In Indonesia's positive law, namely in the Criminal Code, euthanasia or murder at the request of the victim is regulated in the provisions of Article 344 of the Criminal Code, which states that.

"Whoever robs another person's life at the request of the person himself, which is clearly stated with sincerity, is threatened with a maximum imprisonment of twelve years"

Based on the provisions of Article 344 of the Criminal Code above, it is concluded that euthanasia is a prohibited act in which the perpetrator can be threatened with a criminal. Thus, in the context of positive law in Indonesia, euthanasia is a crime. However, it should be noted that Article 344 of the Criminal Code can only be applied if it can be proven that there is a genuine request from the victim. ${ }^{12}$

To see further about what kind of acts are formulated in Article 344 of the Criminal Code below will be seen the elements of these criminal acts:

1. The element of eliminating or taking the life of another person,

2. At the request of the person himself. The existence of an element at the request of the person himself indicates that the perpetrator murdered because he fulfilled the request of the victim. So, it was because of a sincere request that the perpetrator committed the murder. In this case, because a person's right to his own life in our positive law is not recognized, the person who murders the victim's request is still punished. This will be different if, a person's right to his own life has been recognized. 13

12 R. Sugandhi. (1980). “KUHP dengan Penjelasannya, Usaha Nasional”. Surabaya. p. 361.

${ }^{13}$ Imron Halimy. "Euthanasia Cara Mati Terhormat Orang Moderen". Surakarta: CV. Ramadhani. p.169. 
3. What is clearly stated with sincerity. The existence of an element that is clearly stated with sincerity implies that the request from the victim must really be a request that is clearly stated in earnest. Although it is not explicitly explained what is meant by the term, it is clearly stated with sincerity.

However, it is generally understood that for the existence of these elements, it must be proven that there is a statement from the victim about the seriousness of having his life taken away. Proof of these elements, for example, can be proven by the presence of witness statements or a written statement.

\subsection{Human Rights and Euthanasia}

The Netherlands as a legislator in the formation of laws that are still being implemented in Indonesia to this day highly upholds the existence and guarantees of human rights, especially the right to life. This is proven that in the Criminal Code regarding the safety and security of the human soul, it is still guaranteed without the slightest change. It is a fact up to now, that regardless of religion, race, color, and ideology, the safety and security of the human soul in Indonesia is guaranteed by law. This is also a reflection of the principle of equality before the law which of course must also be applied to the security and safety of the human soul.

Basically, the meaning of euthanasia is the termination of life which is carried out at the request of the person himself which is expressed with sincerity, but in reality, many people want euthanasia not of the will of the person himself but the request was submitted by the husband, parents or family of the sufferer. In terms of legislation, currently, there is no new regulation regarding this euthanasia, but after all, this euthanasia issue concerns the safety of the human soul. However, that does not mean that euthanasia is allowed.

This makes doctors faced with a dilemma to perform euthanasia in order to fulfill the request of the patient or patient's family or refuse. A doctor has to help the soul of a patient but on the other hand, if the treatment is continued it will prolong the patient's suffering and be in vain because the diagnosis shows that the patient's life expectancy is very small. Stopping aid is a form of euthanasia. 
Euthanasia can also be indicated as an act of premeditated murder that has been planned and desired by certain parties. Active euthanasia is not always requested by the patient concerned, it may be that active euthanasia or lethal injection is requested by the patient's family who does not rule out wanting the patient to die even though it is based on reasons that can be accepted by common sense such as the inability to pay for the patient's care and treatment. or sorry to see the suffering experienced by the patient.

In this case, the crime of the soul has been regulated in the Criminal Code such as articles 338, 340, 341, 344, and 359. We can also know how the actual formation of this law upholds the human soul, because the Dutch era has also considered the human soul as property value compared to other human rights.

In positive law that is currently still in force in Indonesia, such as the following articles that regulate the human soul, namely articles 338, 340, 344, and 359, it may be necessary to regulate the material which basically consists of 3 (three) criminal events, namely:

1. Ending the life of another person at the victim's request which is stated clearly and earnestly.

2. Helping others to end their lives or providing the means.

3. Encourage others to end their lives.

Types of euthanasia are seen from the person who proposes euthanasia, namely:

\section{Euthanasia Proposed by Sufferers}

To anticipate the consequences of the development of medical science regarding mental crimes, the author describes the articles that can ensnare him. Article 344 of the Criminal Code, in this article murder, is carried out at its own request which is clearly stated with sincerity and this is imposed on positive euthanasia. As we know that Article 344 of the Criminal Code, known as active euthanasia, states that anyone who takes another person's life at his own request who states with sincerity, is threatened with a maximum imprisonment of 12 years. 
With the inclusion of Article 344 of the Criminal Code, the legislators must have suspected beforehand that euthanasia had occurred in Indonesia and will also occur in the future. However, the formulation of the article creates difficulties in proving that there are words "at one's own request" accompanied by the sincerity in which the person asking has died.

It is conceivable that the person who stated with all sincerity has died, then another problem arises, what if the person concerned is unable to communicate. For example, in a case that is not dead, he is not alive because he can only survive on a respirator (breathing aids) and he cannot speak and move. Then the husband or father of the person demands that his wife or child be declared in his authority and appointed as authorized representatives to stop all medical actions.

Furthermore, the court rejected the claim because according to its decision that the child had the right to decide whether or not to use a respirator. Of course, this is impossible because his wife or child cannot and cannot decide, and in the end, he died.

\section{Euthanasia Proposed by Non-Sufferers}

From several examples of euthanasia cases that have recently been widely reported, the request for euthanasia is not actually euthanasia in accordance with the category of article 344 of the Criminal Code because euthanasia is an act where the elements are carried out "at their own request" so that if the husband or father of the sufferer requests euthanasia cannot be categorized as article 344 of the Criminal Code but can be categorized as another article which is still an article on the crime of murder.

First, article 340 of the Criminal Code, that the murder must-have elements of preplanned, meaning that the intention to kill with its execution still has time (time) for the killer to calmly think about it. This article can be imposed on negative euthanasia.

Second, article 345 of the Criminal Code, in this article regulates euthanasia which in this case the death that occurs is caused by the patient knowing that his illness is not getting better and of course the patient knows from the doctor, so the patient wants his death to be accelerated by refusing medical treatment. And the doctor allowed it. 
From this, the author concludes that the doctor's notification to his patient is an attempt to deliberately encourage others to perform euthanasia and as a result, the patient refuses medical treatment so that death occurs as soon as possible.

Third, article 359 of the Criminal Code, this article can be applied to the type of passive euthanasia. The negligence or failure of a doctor to take action to prevent death is an element "because his fault causes someone's death". Then continued with article 304 of the Criminal Code, in that article, there is an element of "deliberate acts causing or letting people in misery", This element is in accordance with the doctor who knows that the treatment to be given to the patient is in vain so that the doctor leaves the patient. Then the main condition for the occurrence of euthanasia in article 306 (2) where the element of an unlawful act is "if the act causes death". Fourth, Article 338 of the Criminal Code, because this article is an article that is more general in nature in cases of murder in the case of euthanasia, then this article is a subsidiary article to articles that are more specific in nature.

In Indonesian Criminal Law, especially in the Criminal Code, it has provided legal protection for 3 things that are considered very important, namely life or body, honor, and property. In this case, euthanasia is included in the protection of life. The problem is, in the case of euthanasia, there is usually a dilemma, whether it is better to "save" the patient's life or "persecute" him. Thus conceptually the issue of euthanasia is still a debate that has not ended. Without intending to extend the conceptual debate on this issue, the following will describe how positive law in Indonesia provides regulations on this issue Indonesian Criminal Law, especially in the Criminal Code, it has provided legal protection for 3 things that are considered very important, namely life or body, honor, and property. In this case, euthanasia is included in the protection of life. The problem is, in the case of euthanasia, there is usually a dilemma, whether it is better to "save" the patient's life or "persecute" him. Thus conceptually the issue of euthanasia is still a debate that has not ended. Without intending to extend the conceptual debate on this issue, the following will describe how positive law in Indonesia provides regulations on this issue. 
In our positive law, the issue of euthanasia or murder at the request of the victim is regulated in Article 344 of the Criminal Code which states:

"Whoever robs another person's life at the request of the person himself, which is clearly stated with sincerity, is threatened with a maximum imprisonment of twelve years".

Based on the provisions of Article 344 of the Criminal Code above, it is concluded that euthanasia is a prohibited act in which the perpetrator can be threatened with the criminal. Thus, in the context of positive law in Indonesia, euthanasia is a crime. However, it should be noted that Article 344 of the Criminal Code can only be applied if it can be proven that there is a genuine request from the victim.

To see further about what kind of acts are formulated in Article 344 of the Criminal Code below will be seen the elements of these criminal acts. If the criminal acts formulated in Article 344 of the Criminal Code are described, they consist of the following elements:

1. The element of eliminating or taking the life of another person.

2. At the request of the person himself.

3. What is clearly stated with sincerity.

When viewed at a glance, the criminal acts regulated in Article 344 of the Criminal Code are similar to those regulated in Article 338 of the Criminal Code. However, if you look closely, the two crimes have very basic differences. The differences between the two acts of crime include: The crime regulated in Article 344 of the Criminal Code contains elements at the request of the person himself and elements that are clearly stated with sincerity. These elements are not contained in the criminal acts regulated in Article 338 of the Criminal Code.

Article 344 of the Criminal Code does not explicitly contain the element of intent, while Article 338 of the Criminal Code explicitly contains this element. The explicit absence of the element of intent in Article 344 of the Criminal Code has the consequence that in the trial the element of intent is explicitly formulated, thus this element must be proven in the trial. 
Judging from the maximum penalty that can be imposed, the maximum penalty that can be imposed, in Article 338 of the Criminal Code is heavier when compared to the maximum penalty in Article 344 of the Criminal Code. Based on article 344, the positive law implicitly recognizes the existence of a person's right to his own life, even though not all of them are recognized.

Below will be described the meaning of each element in article 344 of the Criminal Code to further clarify the understanding of criminal acts in article 344 of the Criminal Code.

The element "at the request of the person himself". The existence of an element at the request of the person himself indicates that the perpetrator murdered because he fulfilled the request of the victim. So, it was because of a sincere request that the perpetrator committed the murder.

The element at the request of the person himself also implies that the initiative to commit the murder came from the person himself, not the perpetrator. The perpetrator only fulfills the request of the victim.

This element at the request of the victim is important to see where the murder initiative came from. Because in this case, if the murder initiative is not from the victim himself but from someone else, then the act is included in the formulation of Article 345 of the Criminal Code.

In this case, it is generally understood that a request is a statement of will addressed to another person in the hope that the other person will act in accordance with the interests of the person requesting it.

In the case of the victim's request, what if the person who is asked to kill is under pressure (psychic) so that the request can be fulfilled. For example, the victim threatens, with threats of violence or threats to reveal personal secrets to the person requested. However, it is necessary to consider how severe the threat is, if the threat will endanger the life of the perpetrator and eventually the murder is committed, then he cannot be convicted. As has been regulated in several Supreme Court jurisprudence, for example, the decision dated 27-1972 No. 72 K/K1970 which states that "even 
though what is alleged is a formal offense, the Judge must materially pay attention to the possibility of the circumstances of the accused on the basis of which they cannot be punished (materialele wederrechtelijkheid).

The element "which is clearly stated with sincerity". The element that is clearly stated with sincerity implies that the request from the victim must really be a request that is clearly stated in earnest.

The perpetrator must be able to prove the existence of such a request to the Court. If the perpetrator cannot prove a genuine request, then the crime of murder is no longer murder at the request of the victim as regulated in Article 344 of the Criminal Code but is an ordinary murder act as stipulated in Article 338 of the Criminal Code.

How to prove the existence of a request that is clearly stated with sincerity? Although it is not explicitly explained what is meant by the term, it is clearly stated with sincerity. However, it is generally understood that for the existence of these elements, it must be proven that there is a statement from the victim about the seriousness of having his life taken away. The proof can be done by means of witnesses, or by providing written statements to fulfill the elements clearly stated with sincerity.

In this case, because a person's right to his own life in our positive law is not recognized, then the person who commits the murder at the request of the victim is still being punished. This will be different if, a person's right to his own life has been recognized. Which brings consequences that can not be punished by the perpetrator. For example, in developed countries, especially in Europe and America, there seems to be a tendency to recognize the right to one's life even under certain conditions. In Japan, for example, there is already a jurisprudence that allows euthanasia under certain conditions. Even based on The Natural Death, a doctor who refuses someone's desire to shorten life or remove life aids which the patient considers to slow down the death process or prolong the suffering period can be prosecuted in court.

The case of euthanasia, in Indonesia, was filed in 2004. Hasan formally submitted a request for euthanasia against his wife to the Central Jakarta District Court. On the same day, Hasan asked the Minister of Health to determine euthanasia. However, the 
Central Jakarta District Court rejected the application because it was considered unlawful. The Minister of Health who served at the time, Siti Fadillah Supari, gave a solution for the request, that the cost of care and treatment for Mrs. The share will be borne by the government. This is considered the best way to do a lethal injection of Mrs. Again. Unexpectedly on January 6, 2005, Mrs. Agian who had been in a coma for months had regained consciousness.

In 2005 at Pasar Rebo Hospital, East Jakarta, according to data obtained from the Bali Post, the request for euthanasia was submitted by Rudi Hartono to his wife Siti Zulaeha who had been unconscious for 6 months after undergoing cesarean section for her second child. The application for active euthanasia or lethal injection was submitted by Rudi Hartono to the Central Jakarta District Court, whose report was immediately received by the Chairman of the Central Jakarta District Court, I Made Karna. Rudi's reason for applying for lethal injection is not much different from Hasan's reason in the case of Mrs. Again, previously, that Siti Zulaeha's condition at that time was in a vegetative state (total paralysis) and there was no other way to release her wife from this suffering except by lethal injection as stated by Rudi to the Chairman of the Central Jakarta District Court.

In 2011 the application for lethal injection (active euthanasia) by a poor family of Kardjali Karsoud (69 years) was related to breast cancer which was suffered by his wife, Samik (52 years) in the city of Surabaya to be exact at Dr. Hospital. Soetomo, Surabaya. However, the request for euthanasia was again not granted by the Court.

The application for euthanasia is usually submitted in cases of certain diseases, one of which is in cases of cancer patients who can no longer endure their suffering, both psychological fatigue, can not stand the pain caused by cancer and also the fact that the results of the doctor's diagnosis state the disease. Cancer suffered can no longer be cured because it is in a terminal stage which if treated can only improve the patient's quality of life. On average, those who apply for euthanasia are cancer sufferers because they feel the pain that the sufferer can no longer tolerate. 
Euthanasia is not an essential value of the Indonesian state because the values of the Indonesian nation do not teach that death can be done with the help of other people, including the help of a doctor. A person should die naturally or according to the will of Allah SWT. Unlike in the Netherlands or America, which have legalized euthanasia. So it can be said that euthanasia is not in accordance with human values that are upheld and used as the philosophical foundation of the Indonesian state.

Euthanasia is very clearly contrary to the values in Pancasila as the philosophical foundation of the state and the 1945 Constitution. Contrary to Pancasila means that it is not in accordance with the existing precepts, especially the 1st principle, namely Belief in One God, and the 2nd principle, namely just and civilized humanity. The 1st precept when associated with euthanasia means that God is the one who determines one's life and death. If someone applies for euthanasia to end his suffering, it has preceded the provisions that have been determined by Allah SWT. The second precept means that every action taken by a person must consider the feelings of others and see the rights inherent in a person in accordance with the rights contained in the Human Rights Act. Euthanasia is clearly not in accordance with the meaning of this 2nd precept because euthanasia aims to end the life of someone who according to the opinion of most people is very uncivilized even though the termination of life is based on the request of the patient himself or by the patient's family. Euthanasia is also not in accordance with the norms that exist in Indonesian society, be it religious norms, customary norms or legal norms.

Euthanasia will be difficult if applied in Indonesia because the Indonesian nation is a nation that respects human values as the philosophical basis of the Indonesian state in accordance with the precepts of Pancasila. euthanasia because it is not in accordance with the philosophy of the Indonesian state which upholds human values and also violates human rights values in the Human Rights Law, namely the right to life. In addition to being contrary to the 1945 Living Law, euthanasia is also not in accordance with the value of justice so that euthanasia is not justified in the 1945 Constitution, other laws and regulations as well as in the Medical Ethics Code. 


\section{Conclusion}

It can be concluded that euthanasia is very contrary to the philosophy of the Indonesian state which upholds human values and is also not in accordance with the norms in society, namely religious norms, customary norms, and legal norms. However, not a few also support euthanasia. The argument that is widely used is the patient's right to die which is considered a human right that is owned by every human being as well as a person's right to life. According to them, if the patient has reached the end of his life, he has the right to request to apply for euthanasia so that his suffering ends immediately. Euthanasia or suicide with the help of another person simply hastens his death without unnecessary sufferin.

\section{References}

\section{Books}

Halimy, I. (1990). "Euthanasia Cara Mati Terhormat Orang Moderen". Surakarta: C.V. Ramadhani.

Hasan, M.A. (1995). “Masail Fiqhiyah Al-Haditsah Pada Masalah-Masalah Kontemporer Hukum Islam". Jakarta: RajaGrafindo Persada

Soekanto, S. and Mamudji, S. (2001). "Penelitian Hukum Normatif: Suatu Tujuan Singkat, Cet. V". Jakarta: Raja Grafindo Persada.

Tumpa, H.A. (2009). "Peluang dan tantangan Eksistensi Pengadilan HAM di Indonesia". Makassar: PUKAP Indonesia.

Tongat. (2003). "Hukum Pidana Materiil". Malang: UMM Press.

Utomo, S.B. (2003). "Fiqih Aktual Jawaban Tuntas Masalah Kontemporer". Jakarta.

\section{Journals/ Articles}

Dewi, L. (2007). "Hak Asasi Manusia Di Indonesia Ditinjau Dari Berbagai Aspek Kehidupan." Jurnal Hukum \& Pembangunan 37 (4): 499.

Jumiati. (2006). "Materi Negara Hukum Dan Hak Asasi Manusia Dalam Pembelajaran Di Sekolah Menengah." Demokrasi 5 (2).

Perangin-angin, I.I.P., Rahayu., Dwiwarno. N. (2019). "Kewajiban Dan Tanggungjawab Negara." Diponegoro Law Journal 8 (2019): 457-483.

Siregar, A. "Eutanasia Dan Hak Asasi Manusia." (2015). Jurnal Hukum To-Ra Hukum FH UKI 1 (3): 193.

Sukarwarsini, Dj. (2006). "Diplomasi Hak Asasi Manusia Tantangan Bagi Indonesia." Jurnal Hukum Pro Justitia 24 (4) Oktober: 410-425. 